\title{
COMPARATIVE ANALYSIS OF THE CUSTOMS REGULATION OF VEHICLE IMPORT IN THE G20 COUNTRIES
}

\author{
Lesia Hrytsyna ${ }^{1}$, Olena Kharun ${ }^{2}$, Margaryta Dzuba ${ }^{3}$
}

\begin{abstract}
The purpose of this article is to conduct a comparative analysis of customs regulation procedures for the import of vehicles operating in the G20 countries, to determine the possibility of adapting and using their experience in order to improve the customs procedure in force in Ukraine. Since most researches of Ukrainian scientists mainly concern the adaptation of existing customs procedures to the requirements of the UkraineEU Association Agreement and the search for ways to solve the problem of shadow schemes of vehicle import, the selected research purpose is relevant. The subject-matter of the study is the procedures for customs regulation of the import of vehicles of the G20 countries. Methodology. To achieve this purpose, a set of general scientific methods was used that ensure the objectivity and validity of the results obtained, namely, methods of abstraction, comparison, analysis and synthesis, generalization. Results. The research results showed that Ukraine is far behind the leading countries in terms of implementing the standards of environmental and technical safety of imported vehicles. If compliance with the requirements of environmental safety, namely compliance with European standards, is still taken into account when importing, then the issues of technical safety are not regulated by the current customs procedure. Secondly, the system of taxes and payments that are paid in Ukraine upon importation, namely duty, excise duty, and VAT, does not provide for compensation for the negative impact of imported vehicles on the environment. Thirdly, comparing the practice of temporary importation of vehicles operating in the G20 countries and Ukraine has allowed highlighting a number of inconsistencies. So, in the G20 countries, only non-residents can use this regime in the vast majority. Citizens of the country are entitled to temporary admission only if strictly defined requirements are met. However, unlike Ukrainian practice, the very procedure for temporary admission implies the absence of requirements for payment of customs duties and other payments, regardless of whether the person who uses it is a resident or non-resident of the country. Practical significance. The conclusions made allow proposing the necessity to amend the current procedure by introducing the practice of confirming the conformity of imported vehicles with the technical requirements for their operation, increasing the tax burden on vehicles with low environmental efficiency, settling the issue of the availability of the regime of temporary admission of vehicles and strengthening control over compliance with this regime. Relevance/originality. Proposals for the adaptation and use of the experience of the leading countries in the field of customs regulation of import of vehicles are a way to prevent the negative phenomena in Ukraine in this area.
\end{abstract}

Key words: international trade, import, customs regulation, vehicles, G20 countries.

JEL Classification: F10, F13, F53

\section{Introduction}

At the present development stage of globalization, no country can remain economically successful without active participation in international trade processes. The development and strengthening of foreign trade relations remain the only effective method of ensuring the exchange of goods and services in order to meet the needs of consumers from different countries. Given that the production of vehicles in Ukraine at this stage is underdeveloped, imports are the main means of saturation of the domestic market. In view of this, the consideration and study of the procedure for the customs regulation of imports of vehicles in order to improve it become of particular relevance. It should be noted that in Ukraine, active work in this direction is carried out mainly at the level of specialized customs and fiscal

\footnotetext{
Corresponding author:

${ }^{1}$ Khmelnytskyi National University, Ukraine.

E-mail: mev2010conf@gmail.com

${ }^{2}$ Khmelnytskyi National University, Ukraine.

E-mail: harunelena74@gmail.com

${ }^{3}$ Khmelnytskyi National University, Ukraine.

E-mail: fmv.margo@gmail.com
} 
institutions, including the subordinated educational and research institutions. Issues of improving customs legislation, improving customs regulation procedures are actively investigated in the work of such scientists as Pryimachenko D. V., Dorofeieva L. M., Leheza Ye. O., Mazur A. V., Prus L. R., Ruda T. V., Slastonenko O. O., Lutsyshyn Z. O. and others. However, most studies in this area mainly concern the adaptation of existing customs procedures to the requirements of the UkraineEU Association Agreement and the search for solutions to the problem of shadow import schemes of vehicles. At the same time, the issue of studying the international experience of customs regulation of imports of vehicles of the leading countries of the world, the search for ways to adapt it to domestic conditions remains beyond the attention of the scientific community.

When preparing this article, our purpose was to carry out a comparative analysis of customs procedures for the import of vehicles operating in the G20 countries, to identify the possibility of adapting and using their experience in order to improve the current Ukrainian procedure.

\section{Customs regulation of the import of vehicles in the $\mathbf{G} 20$ countries}

The study of customs procedures for the import of vehicles operating in the G20 countries allowsidentifying a number of common features that are inherent to them. The first of them is the requirement for compliance of imported vehicle with current safety standards, which are designed to reduce the risk of harm to citizens and reduce the negative impact on the environment. In most of the countries under consideration, there is a severe penalty for violating the requirements that stipulates for a significant fine and/or imprisonment.

So, in Canada, the main statutory documents regulating these issues are the Motor Vehicle Safety Act (1993), Motor Vehicle Safety Regulations, and Motor Vehicle Tire Safety Regulations (SOR/2013-198). In accordance with the applicable procedure, Canada is allowed to import: a) vehicles purchased in the USA and, accordingly, after the registration in the Registrar of Imported Vehicles, must be inspected and certified to comply with applicable safety standards; b) other vehicles that comply with Canadian vehicle safety standards, or those that are not regulated, or are imported temporarily (Canada Border Services Agency. Memorandum D19-12-1, 2016).

In Australia, imported vehicle safety requirements are determined by the Motor Vehicle Standards Act (1989) and developed according to law Third Edition Australian Design Rules (2006). According to the rules, before importing any vehicle into Australia, it is necessary to contact the Department of Infrastructure, Regional Development and Cities to obtain Vehicle Import Approval, which confirms its compliance with the approved rules and standards. Typically, the authorization procedure takes up to 20 business days. Moreover, the owner is responsible for ensuring that the vehicle meets the requirements for the biosafety of imported vehicles and does not contain asbestos. For vehicles equipped with air conditioning or refrigeration systems, there are requirements for the presence of an import license for emissions of ozone-depleting substances and synthetic greenhouse gases (Australian Government. Department of Infrastructure, Regional Development and Cities; Department of Home Affairs, 2018).

In Japan, such a basic document is Road Transport Vehicle Act (Law No. 185 of 1951), according to which it is prohibited to use a vehicle that does not meet the requirements for technical safety and emission level. The testing centre operating under the Ministry of Land, Infrastructure, Transport and Tourism of Japan is responsible for the inspection (Ministry of Land, Infrastructure, Transport and Tourism, 2018).

In the USA, a system of regulatory acts is developed that is designed to protect the domestic market from the import of inappropriate quality vehicles it includes Motor Vehicle Safety Act of 1966, Vehicle Safety Compliance Act of 1988, Motor Vehicle Information and Cost Savings Act of 1972, and Motor Vehicle Information and Cost Savings Act of 1972 with corresponding amendments and additions (U.S. Customs and Border Protection, 2018). In general, vehicles may be imported in the USA under the age of 25 that meet Federal Motor Vehicle Safety Standards. It is also allowed to import vehicles older than 25 years, provided that the confirmation of their compliance with the applicable standards is not required (National Highway Traffic Safety Administration, 2018).

Since Germany, France, and the United Kingdom (the latter as of 1.08.2018) are EU members, respectively, there are uniform rules and requirements on the technical and environmental safety of vehicles in the territories of these countries. In 2007, Directive 2007/46/EC approved the European Community Whole Vehicle Type Approval - the only approach to obtaining a permit for the operation and use of vehicles in the EU. The validation of the vehicle's compliance with the applicable requirements is the receipt of the Certificate of Conformity, valid on the territory of all member countries. At the same time, this Directive (2007/46/EC, chapters IX, X) allows for providing member countries with national (National typeapproval of small series) and individual approvals, which are valid only in the territory of only the country that issued them. As in the USA, old vehicles do not fall under current requirements, the age of which, depending on the type, is $10-25$ years.

The second one is the requirement to pay taxes and fees on imported vehicles. The main tax payable upon import is an import duty, which is calculated on the basis of the customs value of the imported goods. 
There are two main approaches to its calculation traditional and alternative. According to the traditional approach, the customs value of the goods is determined as its contractual value, that is, the price actually paid or payable for goods if they are sold for export to the importing country. At the same time, the additional costs, such as, for example, commission fees to the seller, transport costs, etc., are included in the customs value. An alternative approach is used in case of the impossibility of using the traditional one. In this case, the customs value may be determined by the contract value of identical or similar goods imported into the country or by the estimated value (Agreement on Implementation of Article VII of the General Agreement on Tariffs and Trade 1994, articles 1-24). Source of information about the cost of identical or similar vehicles can be the reference systems that have become actively distributed in a number of countries in Canada it is Canadian Black Book, in EU countries Eurotax, Glass's Guide, and Parker's Guide.

It is worth noting that Japan does not provide for the import duty on vehicles (Japan's Tariff Schedule, 2018, section XVII), while in other countries under consideration - Canada, Australia, the USA, Germany, France, and the United Kingdom - only imports from individual countries with which the agreements on simplification of customs regulation of export-import operations have been signed are exempted from duty. So, in Canada and the USA, duty is not paid if the country of origin of the vehicle is a member country of the North American Free Trade Agreement (North American Free Trade Agreement, Article 302). Similarly, customs duties do not apply to imports of vehicles in France, Germany, and the United Kingdom from other EU member states (Consolidated versions of the Treaty on European Union and the Treaty on the Functioning of the European Union 2012/C 326/01, Article 30). The practice of reducing or completely eliminating customs duties is also applied by the countries that have signed bilateral agreements on trade and economic cooperation. For example, this practice applies when importing vehicles between the USA and Australia (Australia - United States Free Trade Agreement, 2005), Japan and Australia (Japan-Australia Economic Partnership Agreement, 2005), Canada and the EU (Canada-European Union: Comprehensive Economic and Trade Agreement, 2017). Note that this information is relevant as of August 1,2018, and may be changed in course of time.

According to recent studies by Buettner $\mathrm{T}$. and Madzharova B. (2018), the reduction of import duties and the introduction of additional payments (primarily sales tax) as a way to compensate for the loss of customs revenues is a general development tendency for world trade. Thus, among other payments used in the market of vehicles of the G20 countries, sales taxes, excise taxes, environmental and other fees are common. In Canada, there are charges for both national and local sales taxes.
So, owners of imported vehicles pay goods and services tax (GST); harmonized sales tax (HST) and/or provincial sales tax (PST). Additionally, taxes are paid for air conditioning and excessive weight of the vehicle (Canada Border Services Agency. Memorandum D19-12-1, 2016). Owners of vehicles with excessive fuel consumption are subject to taxation in Canada and the USA. Meanwhile in the USA, unlike Canada, the sales tax is exclusively local tax, the size and conditions of which vary depending on the state (U.S. Customs and Border Protection, 2018).

Australia provides for goods and services tax (GST), which is ten percent of the value of taxable imports and, in some cases, a luxury car tax (LCT). The latter is paid at a rate of $33 \%$ of the value that exceeds the defined threshold. For the fiscal year of 2018-2019, the threshold for the payment of luxury car tax is: a) for vehicles with low emissions and fuel consumption 75,526 dollars; b) for other vehicles - 66,331 dollars (Australian Government. Department of Home Affairs, Australian Taxation Office 2018). A similar tax exists in the United Kingdom - owners of vehicles worth more than $£ 40,000$ must additionally pay $£ 310$ a year (Importing vehicles into the UK, 2018).

In Germany, France, and the United Kingdom, the main sales tax is value added tax (VAT), which varies from $19 \%$ to $20 \%$ in the countries concerned. Also, there is a tax on $\mathrm{CO} 2$ emissions in the territory of the EU (Kunert Uwe and Kuhfeld Hartmut (2007), European Commission. Taxes in Europe Database v3). The practice of paying a sales tax also exists in Japan. When importing a vehicle into Japan, it is necessary to pay a consumption tax of $8 \%$ of the value and acquisition tax, which amounts to 3-5\% depending on the type of vehicle and its destination. In Japan, as in Canada, the tax on the excessive weight of a vehicle is widespread the so-called vehicles weight tax (National Tax Agency of Japan, 2018). As a number of researchers note (Lasse Fridstrom та Vegard Ostli (2017), M. Crippa, G. Janssens-Maenhout et al. (2016), Gang Xu, Tomio Miwa et al. (2015)), the application of environmental standards and additional payments, the size of which correlates with the level of environmental safety of vehicles, is a powerful tool used by the world's leading countries to control the internal market.

Special requirements are applied to vehicles temporarily imported into the territory of countries. In this case, it is usually not necessary to confirm the vehicle's compliance with applicable local standards and to pay any taxes or fees. The main requirement put forward in most countries when applying the temporary admission regime is the non-commercial use of the imported vehicle, the provision of guarantees, and its further removal from the country after the expiration of the temporary stay. The temporary import permit is also granted for vehicles imported for the purpose of their participation in exhibitions, demonstrations, tests, etc. 
In Canada, the right to the temporary import of vehicles is provided to tourists and visitors (up to 12 months), to students (for the period of study), to persons with official work permits (up to 36 months). A similar procedure can also be used by Canadians who rent a car in the USA. In this case, the period of stay of a vehicle in Canada is, as a rule, up to 30 days (Canada Border Services Agency. Memorandum D1912-1, 2016). In the USA, in addition to non-residents, the right to the temporary import of a vehicle can also be used by citizens of the country who work abroad and make a short-term visit to the USA (U.S. Customs and Border Protection, 2018).

The right to a temporary, up to 12 months, import of a vehicle on the territory of the country for tourists and temporary residents is provided for by the laws of Japan, Australia. In order to obtain permission for a temporary stay of a vehicle on the territory of Canada, Japan or Australia, you can use the procedure Carnet de Passages en Douane (Carnet de Passages en Douane. Carnet Countrie, 2018).

In the United Kingdom, Germany, and France, the period of temporary stay of a vehicle for non-residents can be up to 6 months. Exceptions to this rule are possible for certain groups of non-residents of the EU, namely students and persons working in the country. In some cases, the right to temporary importation of a vehicle may also be used by EU residents who use official transport services or use a leased vehicle, provided that the company providing the rental services is registered outside the EU (Importing vehicles into the UK, 2018, Temporary importation of a vehicle notregistered in the EU, 2018).

\section{Customs clearance of imported vehicles in Ukraine}

Consideration of the procedure for customs clearance of imported vehicles in force in Ukraine will be carried out in accordance with the abovementioned scheme.

1) Compliance with standards. According to the current legislation of Ukraine, customs clearance and subsequent state registration of imported new and used vehicles are subject to compliance with environmental standards. For the period from January 1, 2016, to December 31, 2019, vehicles imported to the territory of Ukraine are allowed not less than Euro-5 level, starting from January 1, 2020 - not lower than the Euro 6 level. A document that certifies the conformity of vehicles with the requirements of technical regulations and national standards is a certificate or other document confirming compliance, issued in accordance with the legislation of Ukraine, indicating to what level of environmental standards the vehicle conforms by the design (Euro-2 - Euro-6 or another level) (Pro dejaki pytannja vvezennja na mytnu terytoriju Ukrajiny ta rejestraciji transportnykh zasobiv: Zakon Ukrajiny, 2005).
2) Taxes and payments. In accordance with Article 49 of the Customs Code of Ukraine (CCU), the customs value of goods transiting through the customs border of Ukraine is the value of goods used for customs purposes, based on the price actually paid or payable for these goods (Mytnyj kodeks Ukrajiny, 2012). When importing a vehicle into the territory of Ukraine, it is necessary to pay: a) an import duty, the value of which for most types of vehicles is $10 \%$. When importing from EU countries, the duty rate is set lower than the established in the schedule of reduction of customs rates stipulated by the Ukraine-EU Association Agreement. Reduced, in accordance with the Free Trade Agreement between Canada and Ukraine (2017), is also a rate of import duty on vehicles from Canada; $b$ ) in the case of attributing a vehicle to excisable goods, an excise tax is also charged, the rates of which are set in paragraph 215.3 of Article 215 of the Tax Code of Ukraine (TCU). The size of this tax depends on the age of the imported vehicle, the type of fuel used, the engine volume and power; c) value-added tax at a rate set by Article 193 of the TCU. At present, the amount of this tax is $20 \%$ of the amount of customs value, import duty, and excise tax (Pro Mytnyj taryf Ukrajiny: Zakon Ukrajiny, 2013; Podatkovyj kodeks Ukrajiny, 2010).

3) Mode of temporary import of a vehicle. Temporary importation into the customs territory of Ukraine of personal use vehicles for a period of up to one year is allowed both to citizens and non-citizens of Ukraine. Vehicles imported into the territory of the country under this regime cannot be used for commercial purposes, be ungrouped or transferred to the ownership, use or disposal of other persons. At the same time, when non-resident citizens use this regime, the calculation of customs payments and the provision of guarantees are not provided subject to registration of such vehicles in the authorized bodies of foreign states. However, resident citizens, in accordance with the current legislation, are obliged to pay all customs payments which, under the law, are to be paid upon the import of such vehicles and to provide a written commitment to re-export such a vehicle outside the customs territory of Ukraine, in compliance with the applicable terms (Mytnyj kodeks Ukrajiny, 2012).

\section{Conclusions}

Considering the purpose of our research, it is worthwhile to focus on the following aspects. Firstly, Ukraine is far behind the leading countries of the world in implementing the standards of environmental and technical safety of imported vehicles. If compliance with the requirements of environmental safety, namely compliance with European standards, is still taken into account when importing, then the issues of technical safety are not regulated by the current customs procedure. In fact, checking the conformity 
of the vehicle to the technical requirements is carried out already at the stage of its registration, which, in our opinion, contradicts the practice of the countries under study. Secondly, the system of taxes and payments that are paid in Ukraine upon importation, namely duty, excise duty, and VAT, does not provide for compensation for the negative impact of imported vehicles on the environment. According to the analysis conducted, additional payments for excessive fuel consumption, $\mathrm{CO} 2$ emissions are the norm for the leading countries of the world. Thirdly, comparing the practice of temporary importation of vehicles operating in the G20 countries and Ukraine allows highlighting a number of inconsistencies. So, in the G20 countries, only nonresidents can use this regime in the vast majority. Citizens of the country are entitled to temporary admission only if strictly defined requirements are met. In addition, the very procedure for temporary admission implies the absence of requirements for the payment of customs duties and other taxes and fees, regardless of whether the person using it is a resident or non-resident of the country.

Given the above, we believe that the introduction of amendments to the procedure for customs clearance of imported vehicles in Ukraine is extremely relevant. However, it should not be a reaction to the problems that have become exacerbated but a way to prevent negative phenomena by adapting and using the experience of the leading countries. This will be facilitated by the introduction of the practice of confirming the compliance of imported vehicles with the technical requirements for their operation, increasing the tax burden on vehicles with low environmental efficiency, resolving the issue of access to the regime of temporary admission of vehicles, and strengthening control over compliance with this regime.

\section{References:}

Agreement on Implementation of Article VII of the General Agreement on Tariffs and Trade 1994. Retrieved August 12018 from: https://www.wto.org/english/docs_e/legal_e/20-val_01_e.htm\#ArticleI

Australia - United States Free Trade Agreement (2005). Retrieved from: https://ustr.gov/sites/default/files/ uploads/agreements/fta/australia/asset_upload_file148_5168.pdf

Australian Government. Australian Taxation Office (2018). Luxury car tax rate and thresholds. Retrieved August 1 2018 from: https://www.ato.gov.au/rates/luxury-car-tax-rate-and-thresholds/

Australian Government. Department of Home Affairs (2018). Importing a motor vehicle Retrieved. August 12018 from: https://www.homeaffairs.gov.au/busi/cargo-support-trade-and-goods/importing-goods/importing-motor-vehicles

Australian Government. Department of Infrastructure, Regional Development and Cities (2018). Importing Vehicles into Australia. Retrieved August 12018 from: https://infrastructure.gov.au/vehicles/imports/

Buettner, T., Madzharova, B. (2018). WTO membership and the shift to consumption taxes. World Development, 108, 197-218.

Canada Border Services Agency (2016). Memorandum D19-12-1: Importation of Vehicles. Retrieved from: https://www.cbsa-asfc.gc.ca/publications/dm-md/d19/d19-12-1-eng.pdf

Canada-European Union: Comprehensive Economic and Trade Agreement (2017). Retrieved August 12018 from: http://international.gc.ca/trade-commerce/trade-agreements-accords-commerciaux/agr-acc/ceta-aecg/ text-texte/toc-tdm.aspx?lang=eng

Carnet de Passages en Douane (2018). Carnet Countries. Retrieved August 12018 from: https://www.cpdcarnet.com/ carnet-countries

Consolidated versions of the Treaty on European Union and the Treaty on the Functioning of the European Union 2012/C 326/01. Retrieved from: https://eur-lex.europa.eu/legal-content/EN/TXT/?uri= celex\%3A12012E\%2FTXT

European Commission (2018). Taxes in Europe Database v3. Retrieved August 12018 from: http://ec.europa.eu/ taxation_customs/tedb/splSearchForm.html

European Parliament and the Council of the European Union (2007). DIRECTIVE 2007/46/EC establishing a framework for the approval of motor vehicles and their trailers, and of systems, components and separate technical units intended for such vehicles. Retrieved from: https://eur-lex.europa.eu/legal-content/EN/ TXT/?uri=CELEX:32007L0046

Gang Xu, Tomio Miwa, Takayuki Morikawa, Toshiyuki Yamamoto (2015). Vehicle purchasing behaviors comparison in two-stage choice perspective before and after eco-car promotion policy in Japan. Transportation Research Part D: Transport and Environment, 34, 195-207.

Importing vehicles into the UK (2018). Retrieved August 12018 from: https://www.gov.uk/importing-vehiclesinto-the-uk/temporary-imports

Japan Customs (2018). Japan's Tariff Schedule as of April 1 2018. Retrieved from: http://www.customs.go.jp/ english/tariff/2018_4/index.htm

Japan-Australia Economic Partnership Agreement (2005). Retrieved August 12018 from: http://dfat.gov.au/ trade/agreements/in-force/jaepa/Pages/japan-australia-economic-partnership-agreement.aspx

Kunert Uwe, Kuhfeld Hartmut (2007). The diverse structures of passenger car taxation in Europe and the EU Commissions proposal for reform. Transport Policy. 14(4), 306-316. 
Lasse Fridstrom та Vegard Ostli (2017). The vehicle purchase tax as a climate policy instrument. Transportation Research Part A: Policy and Practice, 96, 168-189.

M. Crippa, G. Janssens-Maenhout, D. Guizzardi, S. Galmarini (2016). EU effect: Exporting emission standards for vehicles through the global market economy. Journal of Environmental Management, 183(3), 959-971.

Ministry of Land, Infrastructure, Transport and Tourism (2018). Inspection. Retrieved August 12018 from: http://www.mlit.go.jp/english/inspect/car13e.html

Mytnyj kodeks Ukrajiny [Customs Code of Ukraine] 13.03.2012, № 4495-V. Retrieved August 12018 from: http://zakon5.rada.gov.ua/laws/show/4495-17/print1524226494328254

National Highway Traffic Safety Administration (2018). Vehicle Importation and Certification Requirements. Retrieved August 12018 from: https://one.nhtsa.gov/cars/rules/import/

National Tax Agency of Japan (2018). Information for Taxpayers. Retrieved August 12018 from: https://www.nta.go.jp/ english/taxes/index.htm

North American Free Trade Agreement. Retrieved August 12018 from: http://www.international.gc.ca/tradecommerce/trade-agreements-accords-commerciaux/agr-acc/nafta-alena/fta-ale/index.aspx?lang=eng

Podatkovyj kodeks Ukrajiny [Tax Code of Ukraine], 02.12.2010, № 2755-VI. Retrieved August 12018 from: http://zakon2.rada.gov.ua/laws/show/2755-17

Pro dejaki pytannja vvezennja na mytnu terytoriju Ukrajiny ta rejestraciji transportnykh zasobiv: Zakon Ukrajiny [On some issues related to registration and importing motor vehicles to the customs territory of Ukraine and registration: the law of Ukraine], 06.07.2005, № 2739-IV. Retrieved August 12018 from: http://zakon5.rada.gov.ua/ laws/show/2739-15/print1524226494328254

Pro mytnyj taryf Ukrajiny: Zakon Ukrajiny [Customs Duty Rates of Ukraine: The Law of Ukraine], 19.09.2013, № 584-VII. Retrieved August 12018 from: http://zakon3.rada.gov.ua/laws/show/584-18

Temporary importation of a vehicle not-registered in the EU (2018). Retrieved from: https://www.zoll.de/ EN/Private-individuals/Travel/Entering-Germany/Duties-and-taxes/Temporary-importation-of-a-vehicle/ temporary-importation-of-a-vehicle_node.html

U.S. Customs and Border Protection (2018). Importing a Motor Vehicle. Retrieved August 12018 from: https://www.cbp.gov/trade/basic-import-export/importing-car

Ugoda pro vilnu torgivlyu mizh Ukrayinoyu ta Kanadoyu [Ukraine - Canada free trade agreement] (2017). Retrieved August 12018 from: http://zakon5.rada.gov.ua/laws/file/en/text/53/f466018n6.docx 